\title{
Retrospective Analysis of the Blood Component Utilization in a University Hospital of Maximum Medical Care
}

\author{
R. Georg Geißler ${ }^{\mathrm{a}} \quad$ Dominik Franz ${ }^{\mathrm{b}} \quad$ Hubert Buddendick $^{\mathrm{b}} \quad$ Petra Krakowitzky $^{\mathrm{a}}$ \\ Holger Bunzemeier ${ }^{b}$ Norbert Roeder ${ }^{b, c}$ Hugo Van Aken ${ }^{d}$ Torsten Kessler $^{\mathrm{e}}$ Wolfgang Berdel ${ }^{\mathrm{e}}$ \\ Walter Sibrowski ${ }^{a}$ Peter Schlenke \\ a Institute for Transfusion Medicine and Transplantation Immunology, \\ ${ }^{\text {b } D R G ~ R e s e a r c h ~ G r o u p ~ M e d i c a l ~ M a n a g e m e n t, ~}$ \\ ${ }^{c}$ Chairman of the DRG Research Group Medical Management, \\ ${ }^{\mathrm{d}}$ Department of Anesthesiology, Surgical Intensive Care and Pain Therapy, \\ ${ }^{e}$ Department of Medicine A - Hematology, Hemostaseology, Oncology, Pulmonology, University Hospital of Münster, Germany
}

\section{Keywords}

Patient blood management · Blood supply · Consumption of blood products · Hemotherapy · Medical reporting system · Demography Process management $\cdot$ Health services research

\section{Summary}

Background: Demographic data illustrate clearly that people in highly developed countries get older, and the elderly need more blood transfusions than younger patients. Additionally, special extensive therapies result in an increased consumption of blood components. Beyond that the aging of the population reduces the total number of preferably young and healthy blood donors. Therefore, Patient Blood Management will become more and more important in order to secure an increasing blood supply under fair-minded conditions. Methods: At the University Hospital of Münster (UKM) a comprehensive retrospective analysis of the utilization of all conventional blood components was performed including all medical and surgical disciplines. In parallel, a new medical reporting system was installed to provide a monthly analysis of the transfusional treatments in the whole infirmary, in every department, and in special blood-consuming cases of interest, as well. Results: The study refers to all UKM in-patient cases from 2009 to 2011. It clearly demonstrates that older patients ( $>60$ years, $35.2-35.7 \%$ of all cases, but 49.4-52.6\% of all cases with red blood cell (RBC) transfusions, 36.4-41. $6 \%$ of all cases with platelet (PTL, apheresis only) transfusions, 45.2 $48.0 \%$ of all cases with fresh frozen plasma (FFP) transfusions) need more blood products than younger patients. Male patients $(54.4-63.9 \%$ of all cases with transfusions) are more susceptible to blood transfusions than female patients (36.1-45.6\% of all cases with transfusions). Most blood components are used in cardiac, visceral, and orthopedic surgery $(49.3-55.9 \%$ of all RBC units, $45.8-61.0 \%$ of all FFP units). When regarding medical disciplines, most transfusions are administered to hematologic and oncologic patients (12.9-17.7\% of all RBC units, 9.2$12.0 \%$ of all FFP units). The consumption of PTL in this special patient cohort $(40.6-50.9 \%$ of all PTL units) is more pronounced than in all other surgical or in non-surgical disciplines. Conclusion: The results obtained from our retrospective analysis may help to further optimize the responsible and medical indication-related utilization of blood transfusions as well as the recruitment of blood donors and their timing. It may be also a helpful tool in order to avoid needless transfusions and transfusionassociated adverse events.

\section{Schlüsselwörter}

Patient Blood Management · Versorgung mit Blutprodukten · Verbrauch von Blutprodukten · Hämotherapie - Medizinisches Berichtssystem . Demografie · Prozessmanagement · Versorgungsforschung

\section{Zusammenfassung}

Hintergrund: Die demografischen Daten prognostizieren eine deutliche Alterung der Bevölkerung in hoch entwickelten Ländern. Ältere Patienten benötigen mehr Bluttransfusionen als jüngere. Auch eingreifende Therapien steigern den Verbrauch an Blutprodukten. Zudem reduziert die Überalterung die Gesamtzahl der vornehmlich jungen, gesunden Blutspender. Somit kommt dem "Patient Blood Management" eine immer wichtigere Bedeutung bei der Steuerung des steigenden Blutproduktebedarfs zu. Methoden: Am Universitätsklinikum Münster (UKM) wurde dafür eine fächerübergreifende retrospektive Analyse zum Verbrauch aller konventionellen Blutprodukte durchgeführt. Parallel dazu wurde ein medizinisches Berichtswesen zur monatlichen Analyse des Transfusionsbedarfs klinikweit wie auch auf Abteilungsebene oder für besonders aufwändige Fälle eingerichtet. Ergebnisse: Die hier vorgestellte Studie bezieht sich auf alle vollstationären Patienten der Jahre 2009-2011 am UKM. Sie verdeutlicht, dass der Bedarf an Erythrozyten (RBCs), Thrombozyten (PTL, nur Aphereseprodukte) und Frischplasma (FFP) im Alter zunimmt (> 60 Jahre: nur 35,2-35,7\% aller Fälle, aber 49,4-52,6\%, 36,4-41,6\% bzw. 45,2-48,0\% aller Fälle mit RBC-, PTL- bzw. FFP-Transfusionen) und für Patienten $(54,4-63,9 \%)$ höher ist als für Patientinnen $(36,1-45,6 \%)$. RBCs und FFP werden vornehmlich in der Herz-, Viszeral- und orthopädischen Chirurgie benötigt (49,3-55,9\% der RBCEinheiten, 45,8-61,0\% der FFP-Beutel), während in der nichtoperativen Medizin der Transfusionsbedarf in Hämatologie/Onkologie (12,9-17,7\% aller RBC-Beutel, 9,2-12,0\% aller FFP-Einheiten) am höchsten ausfällt. Hämatologische und onkologische Patienten haben insgesamt den höchsten Thrombozytenbedarf aller Klinikabteilungen (40,6-50,9\% aller PTL-Beutel). Schlussfolgerung: Die Ergebnisse dieser retrospektiven Analyse sollen bei der Optimierung des indikationsgerechten Verbrauchs von Blutkomponenten sowie der dazu zeitlich angepassten Blutspende helfen. Sie sollen nicht notwendige Transfusionen oder unerwünschte Wirkungen solcher Hämotherapien reduzieren.

\section{KARGER}

Fax +497614520714

Information@Karger.de

www.karger.com (c) 2012 S. Karger GmbH, Freiburg

$1660-3796 / 12 / 0392-0129 \$ 38.00 / 0$

Accessible online at:

www.karger.com/tmh
Prof. Dr. med. Peter Schlenke

Institut für Transfusionsmedizin und Transplantationsimmunologie

Universitätsklinikum Münster

Albert-Schweitzer-Campus 1, Gebäude D11, 48149 Münster, Germany

schlenkp@uni-muenster.de 


\section{Introduction}

Demographic data of Germany [1] and of other countries in the western hemisphere clearly shows that the total population decreases, that inhabitants get older [2], and that disease treatment becomes more complex [3, 4]. These changes clearly influence the donation and consumption of blood components $[5,6]$. On the one hand, older patients need more blood transfusions $[7,8]$ as a result of progress in medical sciences and techniques [4]. On the other hand, preferably younger, healthy people fulfill the criteria to donate blood voluntarily $[9,10]$. However, the birth rates continue to decline over the last decades. At the same time, it has been observed that hospitals of maximum medical care, in particular, tend to register more extensive treatments. This is the case within the fields of solid organ transplantation and regenerative medicine or for major surgical interventions. It is also typical for hematology and oncology, especially for patients receiving high-dose chemotherapy regimens, which unavoidably lead to an increase in consumption of cellular blood products and fresh frozen plasma $[5,11,12]$. The increasing use of bone marrow and peripheral blood stem cell transplantations [13] did not unburden the need of blood components. On the contrary, it put significantly more pressure on the extension of the blood supply system [11] in addition to other new, therapeutic approaches and the above mentioned demographic changes.

Growing numbers of patients with alloimmunization, e.g. after gravidity or after episodes of repeated transfusions, complicate the permanent and safe allocation of 'matched' blood components. Due to the variances within patient populations (e.g. hemoglobinopathies such as sickle cell anemia or thalassemia) and transfusion policies, significant differences in country-specific needs of blood supply should be expected.

At present, no concrete evidence exists that 'artificial' oxygen carriers, neither perfluorocarbon- nor hemoglobin-based, could be established in clinical practice within the next years. Thus, this development will actually lead to a nationwide bottleneck of blood supply and, especially, for hospitals with medical disciplines that have high transfusion demands $[5,6$, 9]. It is unlikely that these needs could be completely covered by an increase of blood donors.

The University Hospital of Münster (UKM) is one of 36 university hospitals in Germany. It is an infirmary of maximum medical care with approximately 1,300 beds, 33 departments, and more than 44,000 in-patient cases per year. The level of self-collected and manufactured blood components is almost $100 \%$ for apheresis platelet concentrates (PTL), whereas the level of red blood cells (RBCs) and fresh frozen plasma (FFP) is approximately $60 \%$ and $80 \%$, respectively. The shortages are covered by other blood donation institutes such as the German Red Cross.

Up until now little was known about the national blood supply in Germany and Europe in terms of clinical applications $[5,14]$. Thus, more details, such as an overview of recipi- ents for each blood component involved and the patients' specific indication for blood transfusions categorized into German diagnosis-related groups (G-DRG), are highly desired.

Considering the demographic changes in Germany and Europe in the next 50 years, the divergence between blood component consumption and volunteer blood donation becomes more and more pronounced. The early recognition of this conflict and its translation into public awareness is of utmost importance to proactively developing strategies against shortages in blood supply. This scenario demands an intensification of programs on Patient Blood Management (PBM) in order to ameliorate the blood demand, optimize the patient's outcome, and avoid needless blood transfusions. Prior to the implementation of the PBM program at the UKM, we performed a retrospective analysis of the distribution of all blood products during a 3-year period (2009-2011) in order to precisely evaluate the status quo. Based on these data, we will start a facility-specific PBM program in 2012 which also includes a new monthly based medical reporting system for all transfusion-relevant medical disciplines, a consultant service by specialists in transfusion medicine in order to optimize bedside application, and a multidisciplinary acting task force to address more general issues such as the management of preoperative anemia [15] and blood loss-minimizing surgical techniques.

\section{Material and Methods}

\section{Data Base}

Each event of actually transfused blood components for in-patients is documented by the Institute of Transfusion Medicine and Transplantation Immunology of the UKM on a case-related basis. The documented data contain the type of blood component, the number of issued and transfused bags, and the date of production, issuance and application. All data were evaluated and analyzed with consent of the involved medical UKM departments.

\section{Data Processing}

As part of the internal cost allocation, calculated costs for the different kinds of blood components are added. In preparation for further data processing, other case-related data (e.g. gender, age, length of stay, diagnoses, medical procedures, G-DRG etc.) is considered. In a further step, the case-related patient data is allocated to the performing medical department within a standardized process developed by the UKM Department of Medical Management [16, 17]. The allocation to the performing medical department is an algorithm that assures a comprehensible and reliable assignment of cases in order to enable the department management and hospital management to plan, monitor, and control the operating figures of in-patient treatment. The main criteria of the allocation to the performing medical department are: the complexity of a surgical procedure and the length of stay in a special medical department. There are special regulations to ensure a correct allocation of special circumstances (e.g., severe injuries, bone marrow transplantation, neonates, implantation of defibrillators, etc.). According to this algorithm, the in-patient case data is allocated to one department only, even if the patient was transferred internally during the in-patient stay $[16,17]$.

After allocation to the medical department of main performance the case-related data undergoes a further classification structure to create a 
Table 1. Total numbers of in-patient cases and numbers of in-patient cases with transfusions and transfusional costs at UKM per year

\begin{tabular}{|c|c|c|c|c|c|}
\hline \multirow{5}{*}{$\begin{array}{l}\text { Table 1. Total num- } \\
\text { bers of in-patient } \\
\text { cases and numbers of } \\
\text { in-patient cases with } \\
\text { transfusions and } \\
\text { transfusional costs } \\
\text { at UKM per year }\end{array}$} & & \multicolumn{4}{|l|}{2009} \\
\hline & & \multirow[t]{2}{*}{ all cases } & \multicolumn{3}{|c|}{ cases with: } \\
\hline & & & RBCs & PTL & FFP \\
\hline & \multirow{3}{*}{\multicolumn{2}{|c|}{$\begin{array}{l}\mathrm{n} \\
\% \\
\text { Mio. EUR }\end{array}$}} & 3,683 & 1,327 & 982 \\
\hline & & & 8.3 & 3.0 & 2.2 \\
\hline & & & 1.772 & 2.491 & 0.698 \\
\hline & \multicolumn{5}{|c|}{$\begin{array}{l}{ }^{\mathrm{a}} \mathrm{n}=\text { Absolute accounts } \% \%=\text { cases with transfusi } \\
\text { Mio. EUR = internal calculated costs of transfus }\end{array}$} \\
\hline \multirow{4}{*}{$\begin{array}{l}\text { Table 2. Total } \\
\text { number of in-patient } \\
\text { used transfusion units } \\
\text { at UKM per year }\end{array}$} & \multicolumn{2}{|r|}{2009} & 2010 & \multicolumn{2}{|c|}{2011} \\
\hline & RBCs & 21,007 & 22,622 & \multicolumn{2}{|c|}{23,564} \\
\hline & PTL & 5,962 & 7,131 & \multicolumn{2}{|c|}{6,748} \\
\hline & FFP & 15,521 & 17,847 & \multicolumn{2}{|c|}{18,711} \\
\hline
\end{tabular}

Table 2. Total number of in-patient used transfusion units at UKM per year

\begin{tabular}{|c|c|c|c|c|c|c|c|}
\hline \multicolumn{4}{|l|}{2010} & \multicolumn{4}{|l|}{2011} \\
\hline \multirow[t]{2}{*}{ all cases } & \multicolumn{3}{|c|}{ cases with: } & \multirow[t]{2}{*}{ all cases } & \multicolumn{3}{|c|}{ cases with: } \\
\hline & RBCs & PTL & FFP & & RBCs & PTL & FFP \\
\hline 45,742 & 3,778 & 1,498 & 1,088 & 47,801 & 4,002 & 1,454 & 986 \\
\hline \multirow[t]{2}{*}{100} & 8.2 & 3.2 & 2.3 & 100 & 8.3 & 3.0 & 2.1 \\
\hline & 1.920 & 2.988 & 0.803 & & 2,001 & 2,836 & 0,842 \\
\hline
\end{tabular}

$\begin{array}{lll}1.920 & 2.988 & 0.803\end{array}$

transparent platform of information for the clinician. This system of clinical performance groups (klinische Leistungsgruppen; KLG) was developed in the UKM Department of Medical Management [16]. The KLG system is independent from the G-DRG system. Within the KLG system each in-patient case is assigned to only one group of clinical performance. The allocation process follows a given hierarchy that considers complex cases first. Cases of lower complexity or nonsurgical treatments are accounted in descending order. All steps of the methods described are based on individually developed structures and processes of the UKM.

\section{Data Reporting}

This processed database is the basis for the evaluations described below. The data is updated monthly. It allows a representation of the number of transfused blood components per time unit for each department of the UKM and for each KLG. Comparisons to preceding years' figures are issued regularly. Therefore, longitudinal analysis of the use of blood components or costs, comparing different years of observation, is possible. A further differentiation according to different diagnoses, surgical and nonsurgical treatment, and different medical procedures, by age, gender or special features - such as the duration of mechanical ventilation - can be realized without difficulty. Thus, a differentiated view to special situations of any blood supply in the hospital is possible [16].

\section{Results}

The data of this retrospective analysis include in-patient cases from 2009 to 2011 treated at the UKM. However, blood supply from the Institute of Transfusion Medicine of the UKM also comprises thousands of out-patient cases (e.g. in the state of pre-admission or post-discharge) which are not incorporated here. Furthermore, autologous blood donations were excluded from this report.

On an annual basis, table 1 compares the number of all inpatient treatments to the cases with transfusions of RBCs, PTL, and FFP at the UKM. In 9.1-9.2\% of all cases any kind of transfusion was performed (data not shown in table 1). The internal calculated per-unit costs for this kind of conventional

hemotherapy adds up to EUR 4.9-5.7 million per year. More than half of these costs originate from the collection and manufacturing of PTL concentrates.

At the UKM, an infirmary of maximum medical care, RBCs are the most frequently applied transfusions followed by FFP (table 2). However, the accounts of PTL transfusions are relatively high. Table 2 shows that the absolute numbers of used blood components throughout stay are nearly stable from year to year. In addition, irradiation was required for 4,557, 5,529, and 5,833 RBC units from 2009 to 2011, and for 4,593, 5,921, and 5,711 PTL bags yearly (data not presented in table 2).

Figure 1 clusters the cases with different quantities of transfused blood components $(1,2,3,4,5,6,7-10,11-15$, $>15$ products used per case). The quantitative patterns differ from product to product. RBCs are predominantly transfused by ordering 2 units, followed by 4 or 6 units (fig. 1a). RBC transfusions with more than 10 units are rather infrequent (10.7-12.1\% per year). The data presented in figure 1 refer to cases; therefore, the units were counted independently upon the time period in which these components were transfused. Thus, they are not suitable to indicate patients with massive transfusions defined as ' $\geq 10$ RBCs' within $24 \mathrm{~h}$. The number of cases with PTL transfusions continuously decreases with the amount of transfused units (fig. 1b). At least $37.0-41.5 \%$ of the patients received only one; $21.7-26.1 \%$ of the patients received two PTL units during their entire hospital stay. Vice versa, the quantity of cases with FFP applications approximately rises with the number of transfused components in a similar two-bags order pattern like RBC units (fig. 1c). In each year investigated, 9.1-11.1\% of the patients received only 1 or 2 units of FFP, predominantly children.

The age classification and gender distribution of the patients getting blood components are shown in figures 2 and 3, respectively. Most transfusions are applied in the middle and older age (fig. 2). Especially for RBC and FFP transfusions, the maximum use is indicated more heavily in older patients (71-80 years) as compared to PTL (51-70 years). For patients younger than 51 years old the need of RBCs (fig. 2a) ranges below the average of the referring age classification gained from all UKM in-patient cases (continuous line, arithmetic 

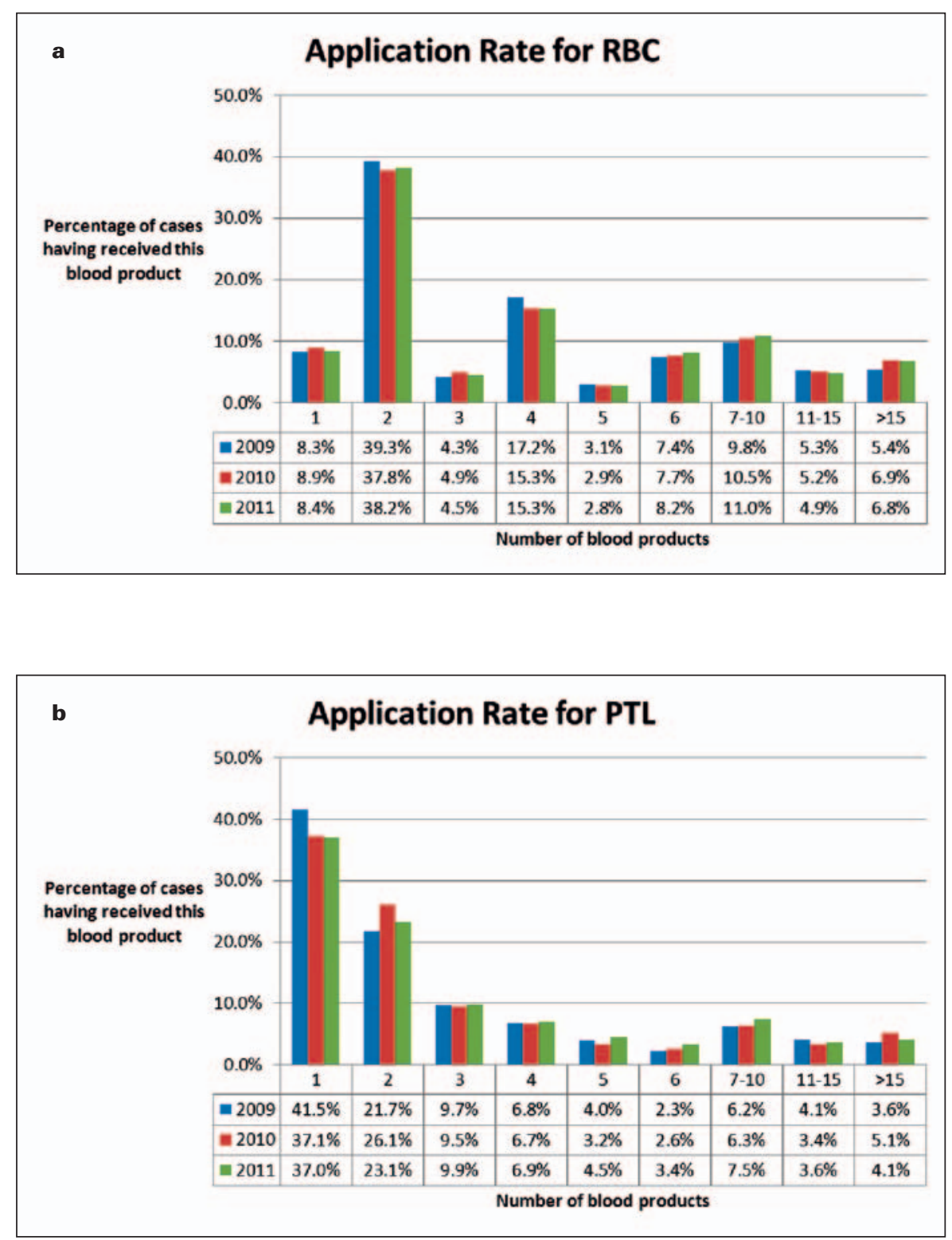

Fig. 1. Clustered numbers of transfused blood units (no. 1, 2, 3, 4, 5, 6, 7-10,11-15, >15) in \% of whole blood consumption. a RBCs, b PTL, c FFP.

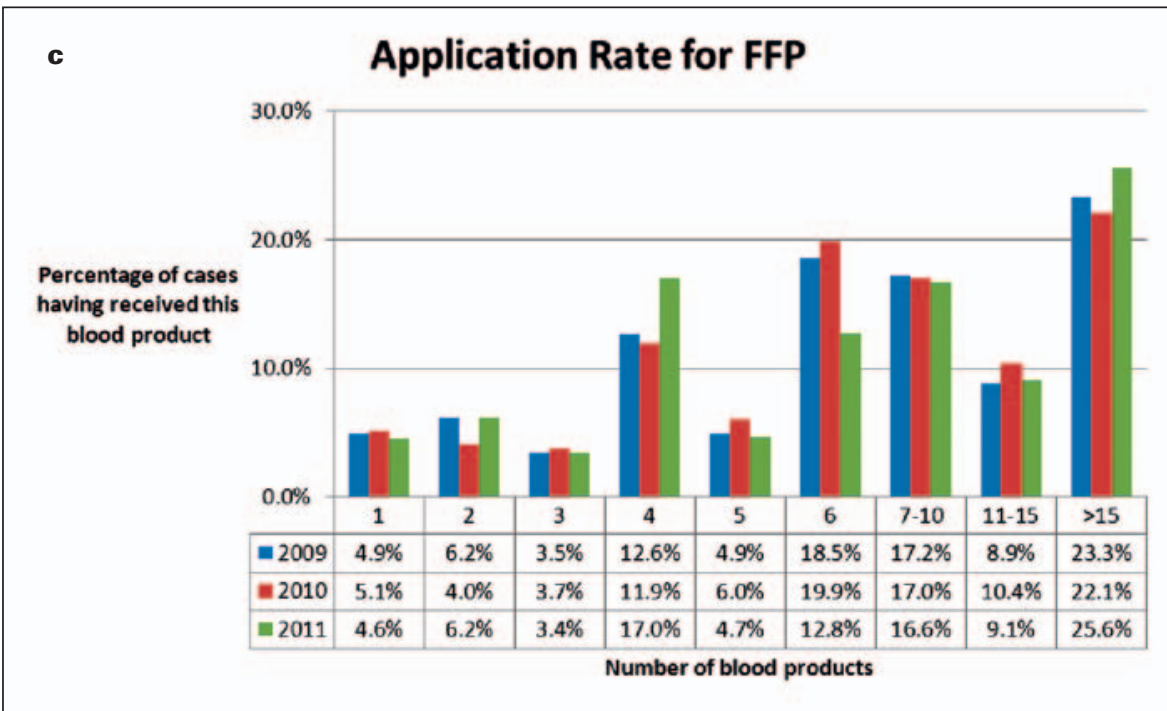



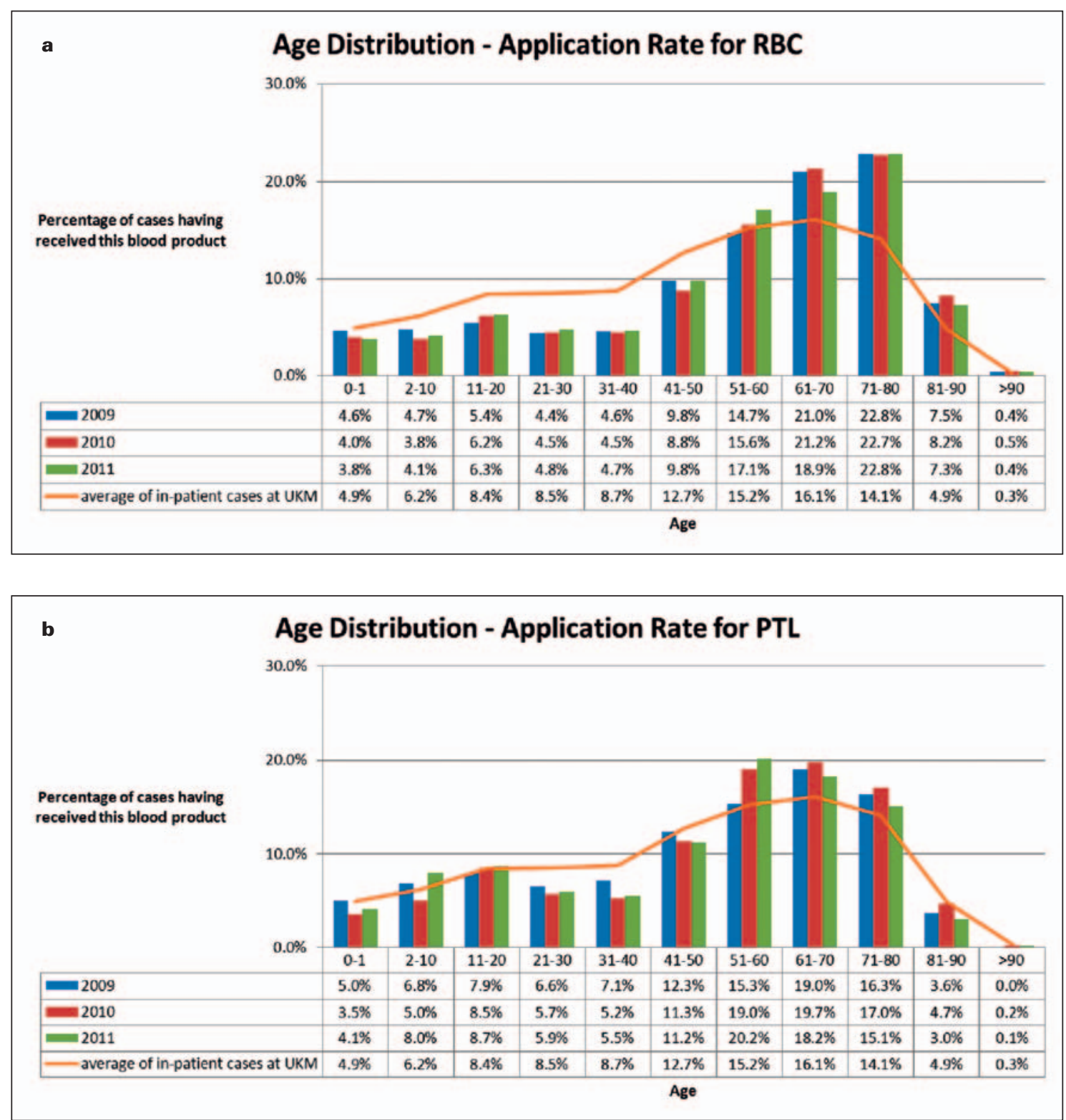

Fig. 2. Age of patients with transfusions (columns) as compared to age of all in-patient cases (line, arithmetic mean of all in-patient cases from 2009 to 2011). a RBCs, b PTL, c FFP.
Age Distribution - Application Rate for FFP

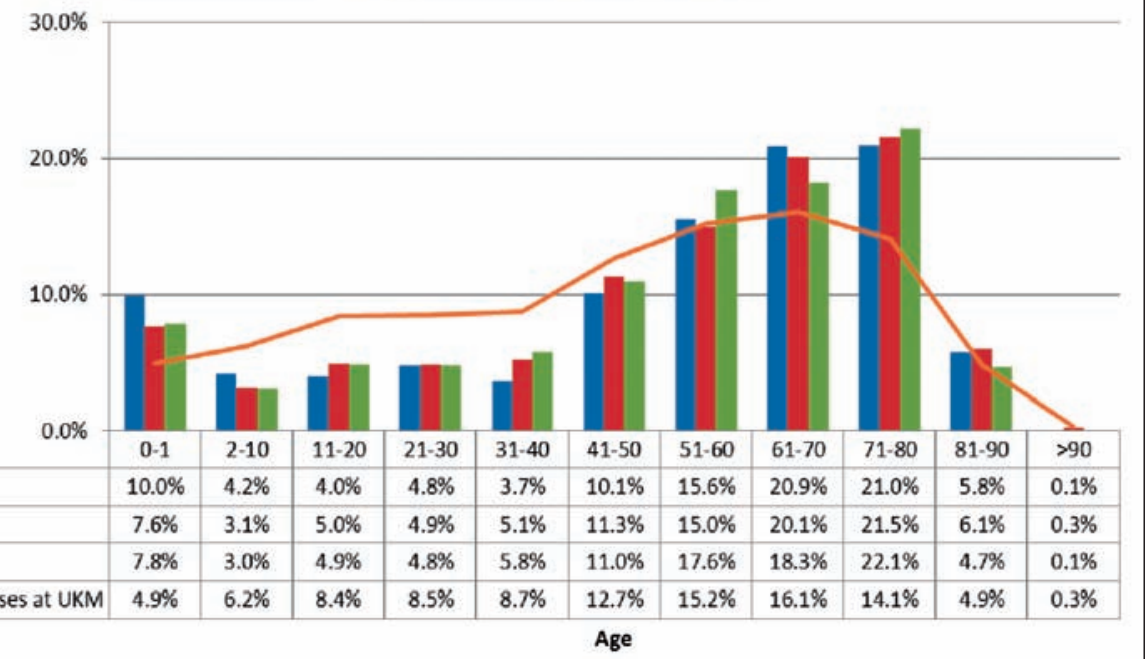



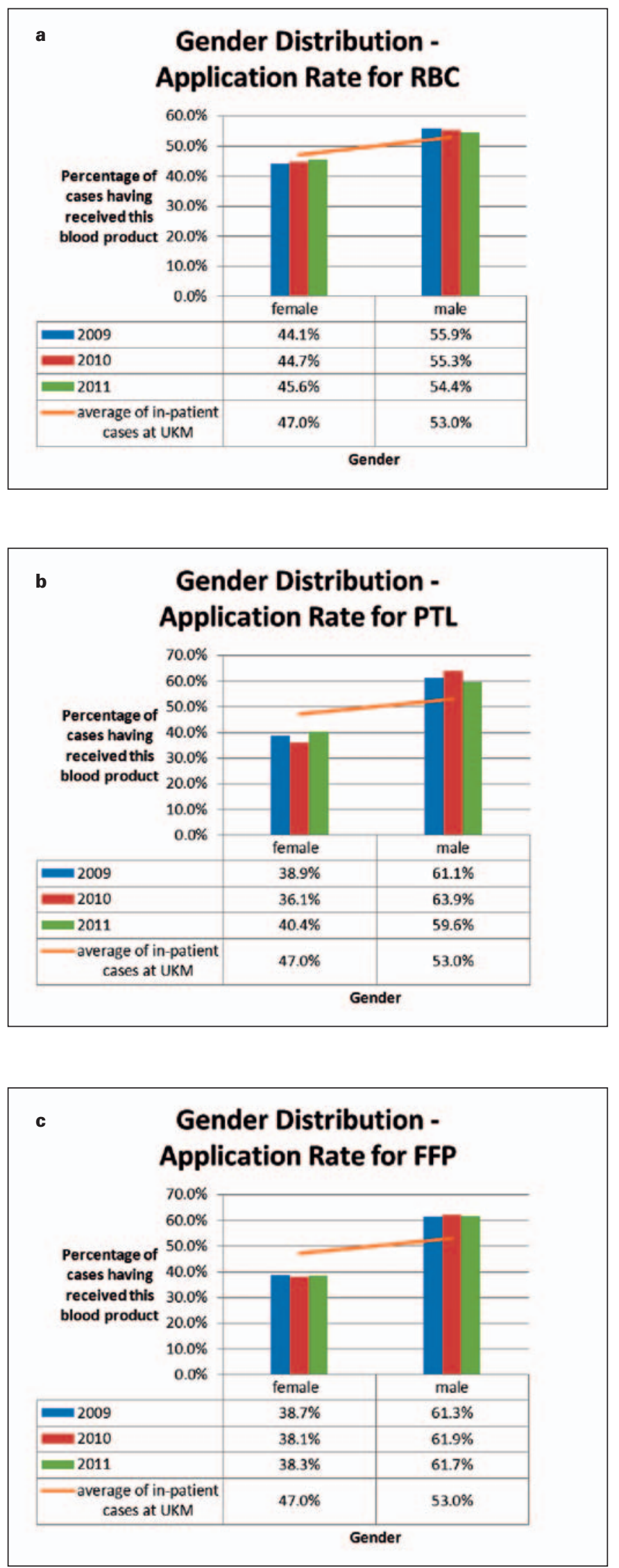

Fig. 3. Gender distribution (columns) as compared to the distribution of all in-patient cases (line, arithmetic mean of all in-patient cases from 2009 to 2011). a RBCs, b PTL, c FFP. mean of patient's age 2009-2011) components. An analogously reduced use of PTL is observed within the age range 21-50 years (fig. 2b). The transfusions of FFP (fig. 2c) are below the average for 2- to 50-year-old patients.

On average, male patients need markedly more blood products than female patients (fig. 3a-c). This gender difference is more pronounced for PTL (fig. 3b) and FFP (fig. 3c) than for RBCs (fig. 3a). However, in contrast to transfusions of ordinary PTL apheresis products, which were applied to male patients in $59.8-66.2 \%, 66.7-80.0 \%$ of all HLA-/HPAadapted PTL units were transfused to female patients (data not shown in fig. $3 b$ ).

Tables 3-5 summarize the total blood consumption separated for each blood component in distinct surgical (tables 3a, 4a, 5a) and non-surgical (tables 3b, 4b, 5b) UKM departments during the years from 2009 to 2011. The data are presented in two different modes: firstly, as 'transfused' cases of the department in relation to all 'transfused' cases of the hospital; secondly, as absolute numbers of transfused units within the department in relation to all transfused units in the infirmary.

The data indicates that the need of transfusions of RBCs and FFP is more pronounced in surgical disciplines, particularly in cardiac, visceral, orthopedic, and trauma surgery (tables 3a, 5a), while PTL are preferentially transfused in nonsurgical cases, above all in the departments of hematology/ oncology of internal and pediatric medicine (table 4b). Furthermore, the treatments of the patients with severe and advanced hematological or oncological diseases also necessitate a great amount of RBC and FFP transfusions (tables 3b, 5b). It is striking that an intensive and sometimes long-lasting hemotherapeutic support is necessary for relatively few patients in these medical areas. Moreover, a lower number of nephrological treatment schedules are responsible for the consumption of higher amounts of FFP (table 5b), especially for plasmapheresis taking into account the increasing ingestions of enterohemorrhagic Escherichia coli toxin in 2011.

\section{Discussion}

The idea of an active PBM becomes more and more en vogue, and in some countries, like Australia, a nationwide campaign is already established. The demographic changes especially in highly-developed countries in Europe or in the USA enforce the necessity to improve strategies for collecting sufficient amounts of blood components from volunteer and healthy donors and to apply these blood products with high efficacy to the patients' benefit [18]. Keeping blood demand and supply in balance will become a significant challenge for countries with an excess of aging in their population.

Therefore, the UKM, as one of 7 university hospitals with maximum medical care in North-Rhine-Westphalia, will proactively address the future problem of safety in national blood supply. To this end we have established a facility-based 
Table 3. Transfusion of RBCs in surgical and non-surgical departments
Table 4. Transfusion of PLT in surgical and non-surgical departments

\begin{tabular}{|c|c|c|c|c|c|c|}
\hline & \multicolumn{6}{|c|}{ Transfusion of RBCs } \\
\hline & \multicolumn{2}{|l|}{2009} & \multicolumn{2}{|l|}{2010} & \multicolumn{2}{|l|}{2011} \\
\hline & cases & transfused units & cases & transfused units & cases & transfused units \\
\hline \multicolumn{7}{|l|}{ Surgical departments } \\
\hline Cardiac Surgery & $22.9 \%$ & $28.4 \%$ & $22.3 \%$ & $27.3 \%$ & $19.7 \%$ & $25.7 \%$ \\
\hline Visceral Surgery & $12.0 \%$ & $18.4 \%$ & $8.7 \%$ & $14.3 \%$ & $9.2 \%$ & $13.6 \%$ \\
\hline Orthopedic Surgery & $11.3 \%$ & $9.1 \%$ & $11.2 \%$ & $9.8 \%$ & $10.9 \%$ & $10.0 \%$ \\
\hline Urology & $5.3 \%$ & $3.4 \%$ & $3.9 \%$ & $2.4 \%$ & $3.7 \%$ & $2.2 \%$ \\
\hline Trauma Surgery & $4.9 \%$ & $6.1 \%$ & $5.1 \%$ & $5.4 \%$ & $5.7 \%$ & $5.3 \%$ \\
\hline Neurosurgery & $4.4 \%$ & $3.2 \%$ & $5.6 \%$ & $3.8 \%$ & $4.9 \%$ & $3.9 \%$ \\
\hline Pediatric Surgery & $3.1 \%$ & $2.2 \%$ & $1.1 \%$ & $1.0 \%$ & $0.8 \%$ & $0.5 \%$ \\
\hline Vascular Surgery & $2.1 \%$ & $1.8 \%$ & $1.9 \%$ & $1.5 \%$ & $2.5 \%$ & $2.5 \%$ \\
\hline Gynecology / Obstretics & $1.4 \%$ & $0.7 \%$ & $1.6 \%$ & $1.2 \%$ & $2.0 \%$ & $1.4 \%$ \\
\hline Otorhinolaryngology & $1.3 \%$ & $0.8 \%$ & $1.4 \%$ & $0.9 \%$ & $1.2 \%$ & $1.0 \%$ \\
\hline Other & $3.1 \%$ & $3.1 \%$ & $3.2 \%$ & $3.2 \%$ & $2.7 \%$ & $2.7 \%$ \\
\hline \multicolumn{7}{|l|}{ Non-surgical departments } \\
\hline Hematology / Oncology, & $11.6 \%$ & $12.9 \%$ & $14.1 \%$ & $16.1 \%$ & $15.2 \%$ & $17.7 \%$ \\
\hline Gastroenterology / Endocrinology & $4.2 \%$ & $2.9 \%$ & $3.0 \%$ & $2.2 \%$ & $3.7 \%$ & $3.0 \%$ \\
\hline Pediatric Hematology / Oncology & $3.6 \%$ & $1.8 \%$ & $4.4 \%$ & $3.2 \%$ & $5.5 \%$ & $2.8 \%$ \\
\hline Cardiology / Angiology & $2.4 \%$ & $1.8 \%$ & $4.0 \%$ & $3.4 \%$ & $3.4 \%$ & $2.6 \%$ \\
\hline General Pediatrics & $2.3 \%$ & $1.1 \%$ & $2.7 \%$ & $1.1 \%$ & $2.3 \%$ & $1.0 \%$ \\
\hline Nephrology / Rheumatology & $1.5 \%$ & $0.9 \%$ & $2.4 \%$ & $1.2 \%$ & $2.8 \%$ & $1.7 \%$ \\
\hline Radiotherapeutics & $1.2 \%$ & $0.6 \%$ & $0.9 \%$ & $0.5 \%$ & $0.7 \%$ & $0.5 \%$ \\
\hline Neurology & $0.7 \%$ & $0.4 \%$ & $0.8 \%$ & $0.6 \%$ & $0.8 \%$ & $0.5 \%$ \\
\hline Transplantation Medicine & $0.5 \%$ & $0.4 \%$ & $1.4 \%$ & $0.7 \%$ & $1.8 \%$ & $1.3 \%$ \\
\hline Pediatric Cardiology & $0.2 \%$ & $0.0 \%$ & $0.3 \%$ & $0.2 \%$ & $0.5 \%$ & $0.1 \%$ \\
\hline Other & $0.0 \%$ & $0.0 \%$ & $0.0 \%$ & $0.0 \%$ & $0.0 \%$ & $0.0 \%$ \\
\hline
\end{tabular}

\begin{tabular}{|c|c|c|c|c|c|c|}
\hline & \multicolumn{6}{|c|}{ Transfusion of PLT } \\
\hline & \multicolumn{2}{|l|}{2009} & \multicolumn{2}{|l|}{2010} & \multicolumn{2}{|l|}{2011} \\
\hline & cases & transfused units & cases & transfused units & cases & transfused units \\
\hline \multicolumn{7}{|l|}{ Surgical departments } \\
\hline Cardiac Surgery & $23.7 \%$ & $15.3 \%$ & $24.7 \%$ & $14.7 \%$ & $16.9 \%$ & $12.0 \%$ \\
\hline Visceral Surgery & $7.7 \%$ & $11.4 \%$ & $4.9 \%$ & $8.3 \%$ & $5.3 \%$ & $5.6 \%$ \\
\hline Pediatric Surgery & $5.4 \%$ & $6.9 \%$ & $1.0 \%$ & $2.4 \%$ & $0.9 \%$ & $0.8 \%$ \\
\hline Neurosurgery & $3.3 \%$ & $2.8 \%$ & $3.9 \%$ & $3.3 \%$ & $3.6 \%$ & $2.2 \%$ \\
\hline Orthopedic Surgery & $3.0 \%$ & $2.0 \%$ & $2.9 \%$ & $1.3 \%$ & $3.0 \%$ & $2.4 \%$ \\
\hline Trauma Surgery & $2.0 \%$ & $1.8 \%$ & $2.2 \%$ & $1.4 \%$ & $2.0 \%$ & $1.5 \%$ \\
\hline Oral / Maxillofacial Surgery & $1.1 \%$ & $1.0 \%$ & $0.7 \%$ & $0.3 \%$ & $0.5 \%$ & $0.2 \%$ \\
\hline Urology & $1.1 \%$ & $1.0 \%$ & $1.1 \%$ & $0.6 \%$ & $0.6 \%$ & $0.3 \%$ \\
\hline Surgical Intensive Care & $0.9 \%$ & $1.0 \%$ & $1.2 \%$ & $0.9 \%$ & $0.8 \%$ & $1.2 \%$ \\
\hline Vascular Surgery & $0.7 \%$ & $0.7 \%$ & $0.6 \%$ & $0.7 \%$ & $1.3 \%$ & $0.6 \%$ \\
\hline Other & $1.5 \%$ & $1.3 \%$ & $2.4 \%$ & $1.5 \%$ & $1.8 \%$ & $1.5 \%$ \\
\hline \multicolumn{7}{|l|}{ Non-surgical departments } \\
\hline Hematology / Oncology & $32.8 \%$ & $40.6 \%$ & $34.2 \%$ & $45.3 \%$ & $37.1 \%$ & $50.9 \%$ \\
\hline Pediatric Hematology / Oncology & $7.8 \%$ & $9.2 \%$ & $9.1 \%$ & $13.1 \%$ & $12.7 \%$ & $12.8 \%$ \\
\hline Gastroenterology / Endocrinology & $2.8 \%$ & $1.3 \%$ & $2.5 \%$ & $1.7 \%$ & $2.8 \%$ & $2.4 \%$ \\
\hline General Pediatics & $2.6 \%$ & $1.5 \%$ & $3.8 \%$ & $2.3 \%$ & $3.7 \%$ & $2.2 \%$ \\
\hline Nephrology / Rheumatology & $1.2 \%$ & $0.6 \%$ & $0.8 \%$ & $0.4 \%$ & $1.4 \%$ & $0.6 \%$ \\
\hline Cardiology / Angiology & $1.0 \%$ & $0.5 \%$ & $0.7 \%$ & $0.3 \%$ & $1.4 \%$ & $0.7 \%$ \\
\hline Transplantation Medicine & $0.9 \%$ & $0.8 \%$ & $2.2 \%$ & $0.9 \%$ & $2.9 \%$ & $1.1 \%$ \\
\hline Radiotherapeutics & $0.2 \%$ & $0.1 \%$ & $0.1 \%$ & $0.0 \%$ & $0.3 \%$ & $0.2 \%$ \\
\hline Pediatric Cardiology & $0.2 \%$ & $0.1 \%$ & $0.5 \%$ & $0.2 \%$ & $0.9 \%$ & $0.3 \%$ \\
\hline Neurology & $0.1 \%$ & $0.1 \%$ & $0.5 \%$ & $0.4 \%$ & $0.1 \%$ & $0.0 \%$ \\
\hline Other & $0.0 \%$ & $0.0 \%$ & $0.0 \%$ & $0.0 \%$ & $0.0 \%$ & $0.0 \%$ \\
\hline
\end{tabular}


Table 5. Transfusion of FFP in operative and non-operative departments

\begin{tabular}{|c|c|c|c|c|c|c|}
\hline & \multicolumn{6}{|c|}{ Transfusion of FFP } \\
\hline & \multicolumn{2}{|l|}{2009} & \multicolumn{2}{|l|}{2010} & \multicolumn{2}{|l|}{2011} \\
\hline & cases & transfused units & cases & transfused units & cases & transfused units \\
\hline \multicolumn{7}{|l|}{ Surgical departments } \\
\hline Cardiac Surgery & $39.3 \%$ & $27.6 \%$ & $37.2 \%$ & $26.8 \%$ & $31.4 \%$ & $20.4 \%$ \\
\hline Visceral Surgery & $14.3 \%$ & $30.4 \%$ & $10.7 \%$ & $23.3 \%$ & $13.1 \%$ & $20.6 \%$ \\
\hline Orthopedic Surgery & $6.9 \%$ & $3.0 \%$ & $9.9 \%$ & $4.3 \%$ & $9.9 \%$ & $4.8 \%$ \\
\hline Pediatric Surgery & $5.5 \%$ & $1.5 \%$ & $2.8 \%$ & $1.7 \%$ & $2.1 \%$ & $0.2 \%$ \\
\hline Neurosurgery & $5.4 \%$ & $2.4 \%$ & $5.7 \%$ & $2.4 \%$ & $6.2 \%$ & $2.3 \%$ \\
\hline Trauma Surgery & $4.3 \%$ & $5.1 \%$ & $4.8 \%$ & $3.5 \%$ & $4.9 \%$ & $3.4 \%$ \\
\hline Urology & $2.4 \%$ & $1.1 \%$ & $1.5 \%$ & $0.8 \%$ & $1.2 \%$ & $0.5 \%$ \\
\hline Vascular Surgery & $1.2 \%$ & $0.9 \%$ & $1.2 \%$ & $1.0 \%$ & $2.5 \%$ & $1.6 \%$ \\
\hline Surgical Intensive Care & $1.2 \%$ & $2.3 \%$ & $1.7 \%$ & $2.0 \%$ & $1.2 \%$ & $1.3 \%$ \\
\hline Oral / Maxillofacial Surgery & $1.1 \%$ & $0.7 \%$ & $0.2 \%$ & $0.1 \%$ & $0.2 \%$ & $0.1 \%$ \\
\hline Other & $2.5 \%$ & $2.3 \%$ & $2.9 \%$ & $5.6 \%$ & $3.1 \%$ & $8.6 \%$ \\
\hline \multicolumn{7}{|l|}{ Non-surgical departments } \\
\hline Hematology / Oncology & $5.6 \%$ & $9.2 \%$ & $6.3 \%$ & $10.8 \%$ & $6.3 \%$ & $12.0 \%$ \\
\hline Gastroenterology / Endocrinology & $3.6 \%$ & $2.2 \%$ & $3.1 \%$ & $2.0 \%$ & $4.9 \%$ & $2.7 \%$ \\
\hline Nephrology / Rheumatology & $2.1 \%$ & $8.0 \%$ & $2.7 \%$ & $10.6 \%$ & $3.7 \%$ & $17.7 \%$ \\
\hline Cardiology / Angiology & $1.9 \%$ & $0.9 \%$ & $2.7 \%$ & $1.3 \%$ & $2.7 \%$ & $1.2 \%$ \\
\hline Transplantation Medicine & $1.2 \%$ & $1.3 \%$ & $2.6 \%$ & $1.0 \%$ & $3.2 \%$ & $1.4 \%$ \\
\hline General Pediatrics & $0.9 \%$ & $0.5 \%$ & $1.7 \%$ & $1.2 \%$ & $1.9 \%$ & $0.8 \%$ \\
\hline Pediatric Hematology / Oncology & $0.5 \%$ & $0.5 \%$ & $1.0 \%$ & $1.1 \%$ & $1.0 \%$ & $0.3 \%$ \\
\hline Pediatric Cardiology & $0.1 \%$ & $0.1 \%$ & $0.6 \%$ & $0.4 \%$ & $0.2 \%$ & $0.0 \%$ \\
\hline Neurology & $0.0 \%$ & $0.0 \%$ & $0.6 \%$ & $0.1 \%$ & $0.3 \%$ & $0.0 \%$ \\
\hline Radiotherypeutics & $0.0 \%$ & $0.0 \%$ & $0.1 \%$ & $0.0 \%$ & $0.0 \%$ & $0.0 \%$ \\
\hline Other & $0.0 \%$ & $0.0 \%$ & $0.0 \%$ & $0.0 \%$ & $0.0 \%$ & $0.1 \%$ \\
\hline
\end{tabular}

PBM initiative and started with first priority a retrospective status quo analysis of the flow of blood components within our institution. To support these efforts, the UKM installed a new case-related data evaluation program. This new medical reporting system enables the creation of an overview of the utilization of all blood components at the UKM, in each department or in a series of particular diagnosis- or proceduredriven in-patient cases. With this helpful tool, cost management for all clinical units and a patient-orientated case management could be performed effectively.

The cases of transfused patients included to this study and the numbers of transfused blood components depend on the severity of the patients' diseases and the complexity of the related therapy. Therefore our results can hardly be compared to other hospitals. In general, the overall consumption and distribution of blood components such as RBCs, FFP, and PTL at the UKM was relatively constant during the 3-year observation period. In addition, a specific distribution pattern is recognizable depending on the blood component or medical discipline. In our study, male patients on average need more RBC, PTL, and FFP transfusions than female ones, and older more than younger patients, confirming results published earlier $[11,12,19,20]$. The age- and gender-related findings for RBC transfusions from the UKM are similar to the results published in other regions [14, 21, 22].
Our data presented here noticeably correspond with the recently published data from a Belgian in-patient study [11], in particular with respect to the quantitative distribution of transfusions of the different blood components to surgical and medical patients and to the major 'transfusional' indications for the three blood products. In the Belgian analysis, transfusions were preferably administered for surgical patients with heart, lung and liver transplants, to those with significant trauma, or to those with diseases of the circulatory system. Yet, in medical cases the leading diagnoses were bone marrow transplants, diseases of the blood and bloodforming organs, poorly differentiated neoplasms, and HIV infections [11]. The distribution of the three analyzed blood components to the different medical disciplines and gender distribution in the UKM schedule also approximately reflect the findings in publications from the USA [19] and the Netherlands [12]. Most blood components were used in cardiac and thoracic surgery, visceral and trauma surgery, in orthopedics, and in hematology/oncology. RBCs and FFP were preferably needed in surgical disciplines while PTL were more used in hematology/oncology. Patients with hematology/oncology treatment and cardiac/thoracic surgery did not only need the highest numbers of transfusion units but also received the most intensive hemotherapies, specified as blood products per person [12, 19, 23]. These findings could 
be conformed in the present study. For RBC transfusions exclusively, similar data were published in Finland [24], in North East England [21], in the USA [19], and in Northern Ireland [20].

As in other hospitals of maximum care, a relatively extensive consumption of PTL products can be observed in the UKM as compared to the country-wide average [25]. Transplantation medicine, adverse effects of intensive chemotherapies, treatment of diseases with acute or chronic disturbance of the blood coagulation, and extensive operations may be some of the reasons for this difference $[11,12,23]$. More than the half of our transfusion-related costs are due to PTL transfusions. However, there are co-payment structures for PTL transfusions and for RBCs within the case-related payment structures of the G-DRG system.

On the contrary, for transfusions of FFP there are no copayments provided within the G-DRG system. Our data face the fact that small amounts of FFP dosages are demanded in some cases, which hardly reach any therapeutic effect, with the exception of pediatric treatment. Therefore, our PBM for FFP shall be optimized, especially by re-evaluation of the medical indications for FFP treatment. Analogously to PTL, the utilization of FFP at the UKM is above the national average [25] which may be caused by high numbers of severely ill patients on the intensive care units with disturbance of the blood coagulation or circulatory shock, in transplantation medicine, or in hematology and oncology.

The longitudinal analysis at the UKM will support the clarification of any saving potential in hemotherapy and of the related costs, not only for FFP. The regular data reporting shall help to concentrate any transfusional treatment on its proven evidence-based benefits [26, 27] and, thereby, minimize the various immunological and non-immunological adverse effects of blood components, which is a well-known result of active PBM [18].

As one further important duty for the future, the task force of PBM in our hospital will have to calculate 'transfusional' indicator data which estimate the mean use of different blood components for the most common operations and other medical procedures to avoid too little or too much procurement of blood components. Basically, PBM should be a door opener to support preoperative assessments of patients with preoperative anemia [15] who prophylactically could be treated with iron $[28,29]$ and economize intra- and postoperative hemotherapy by surgical techniques and by intraoperative cell salvage with autologous re-transfusions [29].
A high acceptance of an active PBM might help to optimize transfusion algorithms within the same hospital or in different hospitals [30, 31]. These transfusion algorithms such as more restrictive or more liberal transfusion regimens have to be permanently adapted to the recent state of the art in science and technology in order to improve the patient's benefit $[32,33]$.

\section{Acknowledgement}

The authors would like to thanks their colleagues of the UKM departments involved in this study for the allowance to publish this paper:

Department of Thoracic and Cardiovascular Surgery, head: Prof. Dr. S. Martens,

Deptartment of General and Visceral Surgery, head: Prof. Dr. Dr. N. Senninger,

Department of Trauma, Hand and Reconstructive Surgery, head: Prof. Dr. M.J. Raschke,

Department of Orthopedic Surgery, head: Prof. Dr. G. Gosheger,

Department of Technical Orthopedics and Rehabilitation, head: Prof. Dr. H.H. Wetz,

Department of Urology, head: Prof. Dr. med. L. Hertle,

Department of Neurosurgery, head: Prof. Dr. W. Stummer,

Department of Pediatric and Neonate Surgery, head: Dr. K. Lohse,

Department of Vascular and Endo-vascular Surgery, head: Prof. Dr. G. Torsello,

Department of Gynecology and Obstetrics, head: Prof. Dr. L. Kiesel,

Department of Otorhinolaryngology, Head and Neck Surgery, temporary head: Prof. Dr. C. Rudack,

Department of Cranio-Maxillofacial Surgery, head: Prof. Dr. Dr. Dr. U.K. Joos,

Department of Medicine B (Gastroenterology / Metabolic Disorders), temporary head: Prof. Dr. K. Hengst,

Department of Cardiology and Angiology, head: Prof. Dr. Johannes. Waltenberger,

Department of Internal Medicine D, Nephrology, head: Prof. Dr. H.-J. Pavenstädt,

Department of Transplant Hepatology, head. Prof. Dr. H. Schmidt,

University Children's Hospital, head: Prof. Dr. H. Omran,

University Children's Hospital, Department of Pediatric Hematology and Oncology, head: Prof. Dr. H. Jürgens,

Department of Pediatric Cardiology, temporary head: PD Dr. H.G. Kehl, Department of Neurology, head. Prof. Dr. Dr. E.B. Ringelstein,

Department of Radiotherapy - Radiooncology, head: Prof. Dr. H.T. Eich.

\section{Disclosure Statement}

The authors declare no conflict of interests.

\section{References}

1 Statistisches Bundesamt, Deutschland: Demographic Development: www.destatis.de/jetspeed/portal/ cms/Sites/destatis/Internet/DE/Navigation/Statistiken/ Bevoelkerung/VorausberechnungBevoelkerung/ VorausberechnungBevoelkerung.psml.
2 Statistisches Bundesamt, Deutschland: Diseases: www.gbe-bund.de/gbe10/abrechnung.prc_abr_test_ logon?p_uid $=$ gastd and p_aid $=5776603$ and $p_{-}$ sprache $=D$ and $p \_k n o t e n=T R 8500$.
3 Statistisches Bundesamt, Deutschland: Blood Donation and Supply: www.gbe-bund.de/gbe10/ trecherche.prc them rech?tk $=14501$ and $t k 2=$ 18502 and $p \_u i d=$ gastd and $p \_a i d=73226435$ and p_sprache $=D$ and cnt_ut $=10$ and $u t=18906$. 
4 Weiser TG, Regenbogen SE, Thompson KD, Haynes AB, Lipsitz SR, Berry WR, Gawande AA: An estimation of the global volume of surgery: a modelling strategy based on available data. Lancet 2008;372:139-144.

$\checkmark 5$ Greinacher A, Fendrich K, Hoffmann W: Demographic changes: the impact for safe blood supply. Transfus Med Hemother 2010;37:141-148.

6 Frey B, Schlenke P: Safeguards in Blood supply: a national and European challenge. Transfus Med Hemother 2010;37:109-110.

7 Vamvakas EC, Taswell HF: Epidemiology of blood transfusion. Transfusion 1994;34:464-470.

8 Wallis JP, Wells AW, Matthews JN, Chapman CE: Long-term survival after blood transfusion: a population based study in the North of England. Transfusion 2004;44:1025-1032.

$\checkmark 9$ Ehling M, Pötzsch O: Demographic Changes in Germany up to 2060 - consequences for blood donation. Transfus Med Hemother 2010;37:131-139.

10 Ritter S, Willand L, Reinhard B, Offergeld R, Hamouda O: Demography and donation frequencies of blood and plasma donor populations in Germany. Bundesgesundheitsbl Gesundheitsforsch Gesundheitsschutz 2008;51:915-925.

-11 Beguin C, Closon MC, Vandekerckhove P, Baele $\mathrm{P}$ : Concentration of transfusion resources on a few pathologies and a few patients: analysis of the comprehensive in-hospital patient database. Transfusion 2007;47:217-227.

12 Brokent-Raven BA, Janssen MP, van der Poel CL, Schaasberg WP, Bonsel GJ, van Hout BA: The PROTON study: profiles of blood product transfusion recipients in the Netherlands. Vox Sang 2010;99:54-64.

13 Baldomero H, Gratwohl M, Gratwohl A, Tichelli A, Niederwieser D, Madrigal A, Frauenhofer K, for the European Group for Blood and Marrow Transplantation EBMT: The EBMT activity survey 2009: trends over the past 5 years. Bone Marrow Transplant 2011;46:485-501.

-14 Seifried E, Klueter H, Weidmann C, Staudenmaier T, Schrezenmeier H, Henschler R, Greinacher A, Mueller MM: How much blood is needed? Vox Sang 2011;100:10-21.
15 Goodnough LT, Maniatis A, Earnshaw P, Benoni G, Beris P, Bisbe E, Fergusson DA, Gombotz H, Habler O, Monk TG, Ozier Y, Slappendel R, Szpalski M: Detection, Evaluation, and management of preoperative anemia in the elective orthopedic surgical patient: NATA Guidelines. Br J Anaesth 2011;106:13-22.

16 Roeder N, Siebers L, Frie M, Bunzemeier H: DRG-Akzeptanz verbessern - Kliniker erreichen mit klinischen Leistungsgruppen. Krankenhaus 2006;5:390-401.

17 Helling J, Bunzemeier H, Fiori W, Siebers L, Brüning K, Gaber A, Frie M, Babapirali J, Roeder N: Klinische Leistungsgruppen - Update und Ausblick. Krankenhaus 2009;9:857-862.

18 Spahn DR, Moch H, Hofmann A, Isbister JP: Patient blood management: the pragmatic solution for the problems with blood transfusions. Anesthesiology 2008;109:951-953.

19 Anderson SA, Menis M, O'Connell K, Burwen DR: Blood use by inpatient elderly population in the United States. Transfusion 2007;47:582-592.

20 Barr PJ, Donnelly M, Morris K, Parker M, Cardwell C, Baillie KEM: The epidemiology of red cell transfusion. Vox Sang 2010;99:239-250.

21 Wells AW, Mounter PJ, Chapman CE, Stainsby D, Wallis JP: Where does blood go? Prospective, observational study of red cell transfusion in North England. Br Med J 2002;325:803-806.

22 Ali A, Auvinen MK, Rautonen J: The aging population poses a global challenge for blood services. Transfusion 2010;50:584-588.

23 Bosch MA, Contreras E, Madoz P, Ortiz P, Pereira A, Pujol MM: The epidemiology of blood component transfusion in Catalonia, Northeastern Spain. Transfusion 2011;51:105-116.

24 Syrjälä MT, Kytöniemi I, Mikkolainen K, Ranimo J, Lauharanta J: Transfusion practice in Helsinki University Central Hospital: an analysis of diagnosis-related groups (DRG). Transfus Med 2001;11:423-431.

25 Henseler O, Heiden M, Haschberger B, Hesse J, Seitz R: Report on notifications pursuant to $\$ 21$ German Transfusion Act for 2007. Transfus Med Hemother 2010;37:29-47.
26 Schlenke P, Sibrowski W: Cross-sectional guidelines: cutting edge in scientific evidence and practical guidance. Transfus Med Hemother 2009;36:351-352.

27 The Board of the German Medical Association on the Recommendation of the Scientific Advisory Board: Cross-Sectional Guidelines for the Therapy with Blood Components and Plasma Derivates. Transfus Med Hemother 2009;36:353-482.

28 Anker SD, Colet JC, Filippatos G, Willenheimer R, Dickstein K, Drexler H, Lüscher TF, Bart B, Banasiak W, Niegowska J, Kirwan BA, Mori C, von Eisenhart Rothe B, Pocock SJ, Poole-Wilson PA, Ponikowski P, for the FAIR-HF Trial Investigators: Ferric Carboxymaltose in patients with heart failure and iron deficiency. N Engl J Med 2009;361:2436-2448.

29 Spahn A: Anemia and patient blood management in hip and knee surgery. Anesthesiology 2010;113: 482-495.

30 Gombotz H, Rehak PH, Shander A, Hofmann A: Blood use in elective surgery: the Austrian benchmark study. Transfusion 2007;47:1468-1480.

31 Biggin K, Warner P, Prescott R, McClelland B: A review of methods used in comprehensive, descriptive studies that relate red blood cell transfusion to clinical data. Transfusion 2010;50:711-718.

32 Hébert PC, Wells G, Blajchman MA, Marshall J, Martin C, Pagliarello G, Tweeddale M, Schweitzer I, Yetisir E, the Transfusion Requirements in Critical Care Investigators for the Canadian Critical Care Trials Group: A multicenter, randomized, controlled clinical trial of transfusion requirements in critical care. N Engl J Med 1999;340:409-417.

33 Carson Jl, Terrin ML, Noveck H, Sanders DW, Chaitman BR, Rhoads GG, Nemo G, Dragert K, Beaupre L, Hildebrand K, Macaulay W, Lewis C, Cook DR, Dobbin G, Zakriya KJ, Apple FS, Horney RA, Magaziner J, for the FOCUS Investigators: Liberal and Restrictive transfusion in highrisk patients after hip surgery. N Engl J Med 2011; 365:2453-2462. 